\title{
Makalah \\ Pemilihan Umum 2019 dalam perspektif Manusia menurut Nietzsche
}

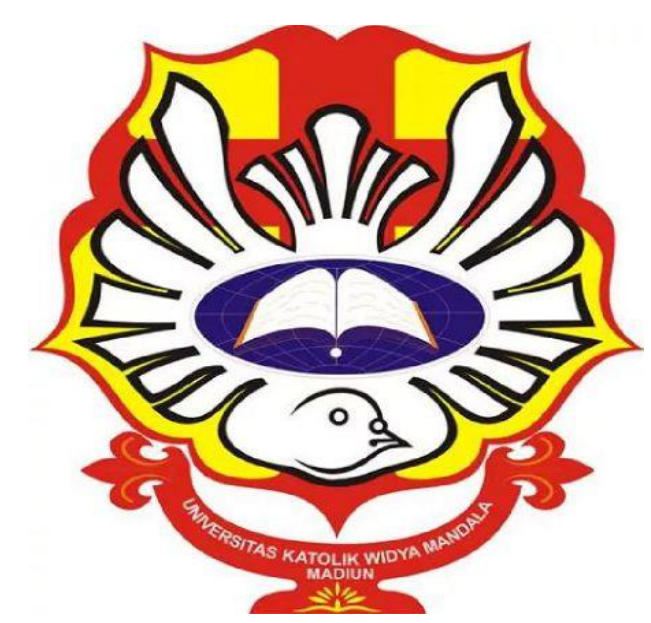

Dibuat oleh:

Ester Dessita Ratna Sari

(41415005)

Dosen pengampu:

Dr. Agustinus Wisnu Dewantara, S.S., M.Hum

PROGRAM STUDI TEKNIK INDUSTRI

FAKULTAS TEKNIK

UNIVERSITAS KATOLIK WIDYA MANDALA MADIUN

2019 


\begin{abstract}
Abstrak
Pemilihan umum (Pemilu) di Indonesia diadakan setiap lima (5) tahun sekali. Pemilihan umum sendiri memiliki azaz yang harus ditaati. Azaz tersebut adalah azaz LUBER JURDIL yang memiliki kepanjangan Langsung, Umum, Bebas, Rahasia, Jujur dan aDIL. Namun pada kenyataan, banyak terjadi pelanggaran pada dari azaz tersebut. Padahal Nietzsche berpendapat manusia haruslah menjadi tuhan atas dirinya sendiri. Hal tersebut dapat dilakukan dengan bisa bertanggungjawab pada diri sendiri, atas segala perbuatan yang telah diperbuatnya. Termasuk tidak melalukan kecurangan.
\end{abstract}

Keyword: Pemilu, Nietzsche, tanggung jawab 


\section{Pemilihan Umum 2019 dalam perspektif Manusia menurut Nietzsche}

Pemilihan umum (Pemilu) di Indonesia diadakan setiap lima (5) tahun sekali. Pemilu sendiri dilakukan untuk memilih berbagai posisi, seperti pemilihan Dewan Perwakilan Rakyat baik di tingkat daerah maupun pusat, pemilihan Kepala Negara dan Wakilnya, pemilihan kepala daerah (Bupati/wakil dan Gubernur/wakil). Atau bahkan pada tingkat terendah seperti Kepala Desa. Pemilihan umum pada dasarnya adalah kesempatan rakyat memilih siapa yang akan menjadi pemimpin dan wakilnya sesuai kandidat yang mendapat suara terbanyak.

Pada pemilihan umum, rakyat/pemilih akan memiliki banyak kandidat yang akan dipilih. Pada kursi Dewan Perwakilan terdapat puluhan kandidat dan hanya sekitar 5-10 saja yang terpilih untuk setiap daerah pemilihan. Di liga pemilihan kepala daerah maupun kepala negara pun tidak ada bedanya. Meskipun berbeda jumlah kandidat, dan lebih sedikit kandidat daripada pemilihan Dewan Perwakilan, namun pemilihan kepala daerah maupun kepala negara juga tidak kalah panas. Posisi kepala daerah maupun kepala negara memiliki nilai prestis tersendiri. Menempati posisi pertama di daerah apalagi negara jelas memiliki nilai yang lebih tinggi.

Pemilihan umum di Indonesia sendiri telah dilaksanakan dimulai dari tahun 1955 dan telah dilaksanakan hingga tahun 2019. Pada tahun ini, pemilihan umum memiliki perbedaan dibanding tahun-tahun sebelumnya, dimana tahun ini rakyat/pemilih dapat memilih anggota Dewan Perwakilan Rakyat Daerah (DPRD) baik kabupaten maupun provinsi, Dewan Perwakilan Daerah (DPD), Dewan Perwakilan Rakyat (DPR), dan Presiden serta Wakil Presiden dalam waktu yang bersamaan. Selain pemilihan yang tersebut di atas, dibeberapa daerah juga melakukan pemilihan umum untuk kepala daerah masing-masing seperti kepala desa. Di daerah Kabupaten Ngawi sendiri juga melakukan pemilihan kepala desa yang hampir serentak di seluruh daerahnya. 
Pemilihan umum sendiri memiliki azaz yang harus ditaati. Azaz tersebut adalah azaz LUBER JURDIL yang memiliki kepanjangan Langsung, Umum, Bebas, Rahasia, Jujur dan aDIL. Langsung berarti pemilih melakukan pemilihan secara langsung tanpa diwakilkan, Umum berarti pemilihan diikuti oleh seluruh rakyat Indonesia yang memiliki hak. Bebas berarti pemilih dapat memilih tanpa paksaan ataupun berada di bawah ancaman pihak manapun. Rahasia berarti suara yang diberikan hanya diketahui oleh pemilih. Jujur dan adil berarti pemilihan umum haruslah sesuai dengan aturan yang berlaku.

Azaz tersebut merupakan azaz yang baik selagi pelaksanaan dilaksanakan dengan baik. Namun pada kenyataan, azaz tersebut hanyalah sebuah slogan yang hampir tidak artinya. Banyak terjadi pelanggaran pada dari azaz tersebut. Kecurangan hampir tidak mungkin tidak terjadi di dalam suatu pemilihan umum. Baik itu di tingkat daerah maupun di tingkat pusat. Baik itu pada pemilihan Dewan Perwakilan maupun pemilihan presiden. Kecurangan terus terjadi.

Pada obrolan beberapa masyarakat terdapat ungkapan, jika ingin menjadi anggota dewan harus bisa bayar harga. Harus mau mengeluarkan uang ratusan juta hingga milyaran. Uang tersebut bukan hanya digunakan untuk melakukan kampanye seperti orasi, memasang banner, kunjungan ke daerah-daerah agar rakyat mengenal kandidat dewan yang akan mewakili suaranya. Namun, ungkapan masyarakat lebih ke arah uang tersebut untuk melakukan suap pada rakyat agar suara pemilih mengalir pada kandidat tersebut.

Banyak cara yang digunakan agar suap tersebut dapat terselubung, seperti dengan mengundang masyarakat/tokoh masyarakat untuk datang pada suatu acara dan dengan dalih memberi seminar kebangsaan, kandidat tersebut memberikan suap pada masyarakat. Ada juga dengan menggunakan beberapa kader yang nantinya akan memberikan uang tersebut kepada warga dari rumah ke rumah. Saat ini, banyak yang percaya suara rakyat dapat dibeli dengan cara tersebut. Cara tersebut juga dikenal dengan nama Serangan Fajar. Tidak jarang melihat calon dewan ataupun calon kepala daerah menjadi bangkrut atau bahkan jatuh miskin karena mengikuti pemilihan umum. 
Selain itu juga terdapat kecurangan lain, seperti saat salah satu kandidat akan melakukan kampanye di suatu daerah dicegat oleh preman yang dibayar oleh lawan pemilunya. Sehingga kandidat tersebut harus pulang dengan tangan hampa karena telah terancam oleh preman-preman tersebut. Padahal jika, kandidat tersebut dapat melakukan kampanye di daerah tersebut, bisa jadi kandidat tersebut dapat memenangkan pemilihan umum.

Pada pemilihan kepala negara juga tidak terhindar dari yang namanya kecurangan. Bahkan bisa dikatakan pada pemilihan umum tahun 2019 ini menjadi pemilihan presiden paling panas karena dipenuhi oleh kecurangan dari calon presiden yang sedang bertanding. Banyaknya black campaign dilontarkan agar dapat menjatuhkan lawan politiknya. Berbagai isu dimuntahkan ke masyarakat agar masyarakat merasa ilfeel pada salah satu pasangan calon.

Isu yang dimainkanpun tidak main-main hingga mampu memecah belah opini rakyat hingga sedemikian rupa. Isu SARA (Suku, Ras, Agama dan Antar golongan) sangat santer dibicarakan. Hingga memunculkan dua kubu utama yaitu cebong dan kampret. Isu-isu tersebut juga diikuti oleh serangan hoax yang merajalela. Bahkan isu tentang Partai Komunis Indonesia (PKI) juga kembali naik ke permukaan. Padahal isu Partai Komunis Indonesia (PKI) termasuk isu yang sensitif mengingat trauma yang disebabkan Partai Komunis Indonesia (PKI) sangat membekas di ingatan masyarakat luas.

Isu agama yang dimainkan juga tidak kalah serius. Isu jika memilih salah satu calon, suara adzan akan dilarang dan umat salah satu agama akan semakin terjepit. Bahkan bermunculan ilmu-ilmu cocoklogi yang tidak masuk akan juga menjamur. Cocoklogi yang dilontarkan beberapa tokoh masyarakat dikaitkan dengan ayat-ayat suci yang berada di dalam kitab suci agama tertentu juga tidak kalah bersaing dengan isu-isu di atas. Terdapat juga isu jika salah satu calon terpilih maka Indonesia akan dijadikan menjadi negara khilafah. Bentuk negara yang ditentang oleh banyak negara dan tidak sesuai dengan ideologi negara kita yaitu Pancasila.

Perpecahan terjadi dimana-mana. Demo yang ditunggangi oleh oknumoknum haus kekuasaan menyebabkan chaos pada masyarakat. Bahkan pihak 
keamanan juga tidak luput dari berita fitnah, sehingga pihak keamanan terkesan tidak pro rakyat dan suka bertindak kekerasan dan tidak mampu menjaga moral. Padahal pihak keamanan hanya berusaha menjaga keamanan agar masyarakat umum/ warga sipil tidak resah atau bahkan terluka yang akhirnya akan menyebabkan kerugian.

Hoax juga tidak berhenti di sana, beberapa oknum memberikan data tidak akurat yang akhirnya menyerang salah satu calon. Tentang utang negara yang menumpuk dan tentang perusahaan-perusahaan Badan Usaha Milik Negara (BUMN) yang dijual ke pihak asing.

Masih banyak fitnah yang bertebaran dalam masyarakat yang tidak mungkin disebutkan semua. Pemilu yang telah melanggar azaz luber jurdil dan melukai ideologi bangsa terjadi begitu saja di depan mata.

Dalam makalah ini, penulis mencoba untuk menelaah masalah tersebut melalui kacamata filsafat. Teori yang mencoba diangkat adalah teori yang dikemukanan oleh Nietzsche. Teori tersebut berisi tentang isi kepala Nietzsche dimana Nietzsche berpendapat Tuhan telah mati. Pendapat tersebut dikemukakan karena Nietzsche melihat sudah tidak ada kebaikan di dunia ini. Sulit sekali menemukan kebaikan di dunia saat ini.

Banyak terjadi chaos sehingga kebaikan sulit ditemukan dalam masyarakat. Padahal Tuhan hakekatnya adalah kebaikan. Jika kebaikan sudah tidak ada lalu dimana Tuhan? Tuhan telah mati karena perbuatan buruk manusia. Perbuatan manusia yang egois dan tidak memperdulikan norma maupun nilai-nilai kebaikan telah membunuh keberadaan Tuhan yang menjadi sumber segala kebaikan. Seharusnya jika Tuhan tidak mati, kebaikan akan selalu ada di dunia karena manusia akan selalu mengingat Tuhan dan akan berusaha dekat denganNya. Mendekat pada Tuhan haruslah berbuat baik.

Dengan kematian Tuhan, Nietzsche berpendapat manusia haruslah menjadi tuhan atas dirinya sendiri. Hal tersebut dapat dilakukan dengan bisa bertanggungjawab pada diri sendiri, atas segala perbuatan yang telah diperbuatnya. Manusia tidak boleh lepas dari tanggung jawab, karena manusia harus menjadi tuan atas dirinya bukan menjadi hamba. Manusia yang menjadi 
tuan dapat memiliki rasa tanggung jawab, tidak seperti manusia dengan mental hamba yang hanya bisa menjadi pesuruh bagi tuannya.

Dalam kacamata Nietzsche tentang kematian Tuhan dapat dilihat dari oknum-oknum yang melakukan tindakanan kecurangan pada saat pemilihan umum. Jika oknum pelanggar tersebut masih memiliki rasa tanggung jawab, tidak mungkin oknum tersebut melakukan tindakan kecurangan seperti menyogok pemilih agar memberikan suara kepadanya. Penyuapan termasuk ke dalam tindakan tercela dan tidak jujur. Mempengaruhi manusia lain dengan cara salah agar mau memilihnya. Kandidat tersebut telah bertindak bertanggungjawab dengan mengabaikan azaz luber jurdil yang aslinya adalah hal baik.

Adanya oknum penyebar fitnah/hoax yang dengan seenaknya menebar berita yang tidak tahu asal dan sumbernya. Bahkan pelaku penyebar hoax tersebut bukan sembarangan orang, melainkan tokoh-tokoh masyarakat yang dapat mempengaruhi banyak pihak. Oknum tersebut tidak segan-segan melontarkan kebohongan dan seakan lepas tangan ketika terjadi kekacauan pada masyarakat karena kebohongannya. Begitu dimintai bertanggungjawaban, oknum tersebut mencari banyak alasan agar dapat terhindar. Mengabaikan panggilan pihak berwajib hingga harus dijemput oleh mobil polisi.

Setelah menyebabkan masyarakat berperang melawan saudaranya sendiri. Terjadi perpecahan dalam keluarga dan membuat masyarakat dengan mudahnya mengatai orang yang tidak sependapat dengannya dengan sebutan tidak pantas (cebong dan kampret yang merupakan nama hewan). Memberikan julukan dengan julukan-julukan rasis seperti China dan antek asing. Membuat masyarakat dengan mudahnya mengkafir-kafirkan saudara. Menciptakan kebencian pada masyarakat yang awalnya tenang menjadi kacau balau.

Memberikan cap bahwa masyarakat dari suku Tionghoa adalah suku yang jahat dan gemar merampas hak masyarakat pribumi, sehingga beberapa masyarakat akan langsung naik pitam ketika melihat orang dengan mata sipit, padahal belum tentu mata sipit itu dari suku Tionghoa. Karena hoaks yang merajalela, menyebabkan banyak masyarakat menjadi takut pada orang-orang yang memakai cadar, berjenggot panjang dengan celana cingkrang. Karena 
oknum-oknum yang mengaku tokoh agama dengan penampilan tersebut menyebarkan berita hoaks dan bahkan dengan mudah berkata kasar serta mengeluarkan kata-kata tidak pantas tentang saudaranya sesama manusia.

Hal tersebut membuktikan bahwa orang berpengaruh belum tentu memiliki mental seorang tuan, malah memiliki mental hamba yang kental. Tidak mau bertanggungjawab dengan kekacauan yang terjadi dan cenderung menyalahkan orang lain. Lari dari tanggung jawab dengan berbagai alasan yang kadang tidak masuk akal. Bahkan beberapa ada yang berencana kabur ke luar negeri begitu kekacauan telah terjadi. Meninggalkan masyarakat yang saling membunuh antar saudara sebangsa.

Memang benar pemilihan umum, setiap kandidat harus bersaing. Namun persaingan tersebut haruslah sesuai norma dan dilakukan scara sehat dan jujur. Bukan dengan menghalalkan segala cara melalui tindakan kotor yang akan menjatuhkan lawan dan memecahbelah bangsa. Sesuai kata Nietzsche, bahwa dengan keadaan di atas menyebabkan oknum-oknum tersebut telah membunuh Tuhan dengan tangannya. Meskipun mereka mengaku bertuhan, tapi pada akhirnya oknum-oknum tersebut tidak menampilkan kebaikan dalam perilaku maupun perkataannya. Melainkan menampilkan keburukan berperilaku dan bertutur kata. Sebagai manusia yang bertanggungjawab, manusia haruslah mampu berbuat baik dan mampu bertanggungjawab pada setiap perbuatannya. Bukan lari dari tanggung jawab dan meninggalkan kekacauan yang telah terjadi. 


\section{Daftar Pustaka}

Dewantara, Agustinus Wisnu. "Pancasila Sebagai Pondasi Pendidikan Agama Di Indonesia." CIVIS 5.1/Januari (2015).

DEWANTARA, AGUSTINUS WISNU. GOTONG-ROYONG MENURUT SOEKARNO DALAM PERSPEKTIF AKSIOLOGI MAX SCHELER, DAN SUMBANGANNYA BAGI NASIONALISME INDONESIA. Diss. Universitas Gadjah Mada, 2016.

https://nasional.kompas.com/read/2019/05/16/10585941/tuduh-pemilu-curangtapi-enggan-buktikan-di-mk-mau-prabowo-apa?page=all 